\title{
Concentrations of metals in liver of Guiana dolphins (Sotalia guianensis) from an estuary in Southeast of Brazil
}

\author{
Salgado, L.D. ${ }^{1,2}$; Más-Rosa, S. ${ }^{3}$; Azevedo, J.C.R. ${ }^{4}$ \\ ${ }^{1}$ Universidade Federal do Paraná, Curitiba, Paraná, Brazil. \\ ${ }^{2}$ Instituto de Pesquisas Cananéia, Cananéia, São Paulo, Brazil. \\ ${ }^{3}$ Faculdade de Ensino Superior e Formação Integral, Garça, São Paulo, Brazil, \\ ${ }^{4}$ Universidade Tecnológica Federal do Paraná, Curitiba, Paraná, Brazil
}

Received February 02, 2018; Accept July 10, 2018

\begin{abstract}
Concentrations of $\mathrm{Fe}, \mathrm{Zn}, \mathrm{Cu}, \mathrm{Mn}, \mathrm{Pb}, \mathrm{Cr}$, $\mathrm{Co}$ and $\mathrm{Ni}$ were measured in the liver of 21 Guiana dolphins from the EstuarineLagoon Complex of Iguape-Cananéia, in order to indicate the impact of their habitat and to verify if these concentrations differ between the sexes and age classes. The concentrations followed the order: $\mathrm{Fe}>\mathrm{Zn}>\mathrm{Cu}>\mathrm{Mn}>\mathrm{Pb}>\mathrm{Cr}>\mathrm{Co}>\mathrm{Ni}$, and with the exception of lead, all concentrations were in the same order of magnitude observed for the species. The accumulations between the sexes were similar, while copper were higher in infants, suggesting that the organ can act as a reservoir for Co in a period of rapidly postnatal growth. Lead mean concentration $\left(3.17 \mu \mathrm{g} \mathrm{g}^{-1}\right)$ were the highest described for the species, which from a toxicological point of view may be a matter of concern. This accumulation suggests a trophic transfer, indicating the contamination of the food chain, which possibly reflects the local environmental contamination caused by ancient lead mining.
\end{abstract}

Key words: Bioaccumulation. Cetaceans. Pb. Sentinel. Sotalia guianensis. Trace elements.

\section{INTRODUCTION}

Metals have great ecological and biological interest, as they are able to pass through bioaccumulation and biomagnification processes. Many of them are essential for the metabolism and life, as others, such as $\mathrm{Hg}$ and $\mathrm{Pb}$, have unknown biological function (Das et al., 2000). In both cases, at high concentrations they become toxic and thus harmful to living beings (O'shea, 1999). They occur naturally in the environment, however, human activities have also released them into the ecosystems, changing their distribution patterns in the globe, which has eventually contaminated several aquatic environments, both continentals and coastal (Yi et al., 2011).

Chemical contamination is considered a major threat to aquatic mammals, especially cetaceans, because of their biological and ecological characteristics, which offer great potential for the accumulation of high levels of contaminants in their tissues (Siciliano et al., 2005; Seixas et al., 2009).
The balance between exposure, absorption and elimination of metals by aquatic organisms heads its input and bioaccumulation into the food chain, and the biomagnification to the top predators' species (Kunito et al., 2004; Moura et al., 2011). These accumulations occur in all species of cetaceans and have different degrees depending on the biological and ecological factors of the species (Lemos et al., 2013; Moura et al., 2014).

The effects of the metals on the body may be lethal or sublethal to all aquatic organisms, which may exhibit responses ranging from subtle adaptations to drastic effects (Reijnders et al., 1999; Das et al., 2000; Yi et al., 2011). However, the potential toxic effects of metals in marine mammals remain unclear since these animals have been exposed to these natural elements for a very long time in evolutionary terms, and because they present mechanisms to control and/or mitigate their toxic effects (Law et al., 1991; O'Shea, 1999; Das et al., 2000; Caurant et al., 2006). These mechanisms include the presence of metallothioneins, 
cytosolic metal-binding proteins, that in mammal's species are primally synthesized in the liver, kidney and intestinal mucosa, whose biological function are related with the regulation of essential metals, such $\mathrm{Zn}$ and $\mathrm{Cu}$, and with the detoxification of toxic metal such Cd and $\mathrm{Hg}$ (Mason et al., 1980).

The liver has greater cumulative potential for metals due to its function in the metabolism of toxicants (Law et al., 1991; Das et al., 2000). Factors such as geographic location, exposure pathways, nutritional status, eating habits, age and sex, visceral distribution, the metabolic rate and the rate of excretion, influence the accumulation of metals in the liver of cetaceans (Das et al., 2000; Moura et al., 2014). It is expected that the concentrations of the essential metals in the liver, such as $\mathrm{Fe}, \mathrm{Zn}$ and $\mathrm{Mn}$, are regulated and present low variability among the animals of the same species (Law et al., 1991; 1992). However, the concentrations of the non-essential metals in the liver of cetaceans are usually scarce, with the exception of cases of exposure to environmental contamination (Law et al., 1991; 1992; Moura et al., 2014).

The Guiana dolphin (Sotalia guianensis - Van Bénéden, 1864 ) is a small odontocete that can reach up to $2.10 \mathrm{~m}$, with estimated longevity about 30-35 years (Rosas et al., 2003). The diet of the species is based on teleost fish, crustaceans and cephalopods (Lopes et al., 2012; Cremer et al., 2012), which in many cases are also intended for human consumption. The distribution of the Guiana dolphin extends from Honduras, in Central America, to Santa Catarina State in southern Brazil (Flores \& Da Silva, 2009). The species displays a coastal distribution with preference for estuarine environments (Flores \& Da Silva, 2009), where they end up being more susceptible to the consequences of the anthropic activities as their habitat exposes these small dolphins to chemicals and pathogens, which can affect their health and therefore their survival (Moura et al., 2014).

Residence patterns are observed in the region of IguapeCananéia (Santos et al., 2001; Oshima et al., 2010), where the animals are seen throughout the year with an estimated population of about 200 animals (Havukainen et al., 2011). Features such as a relatively long lifetime, diet and residential patters make the species a suitable model to monitor the environmental contamination by metals and also the concentrations to which man may be exposed on the consumption of seafood, since, like humans, they can be characterized as final victims of the chemical accumulation process (Moura et al., 2014).

The Estuarine-Lagoon Complex of Iguape-Cananéia is one of the most important estuarine ecosystems of the Brazilian coast, recognized by UNESCO as part of the Biosphere Reserve of the Atlantic Rainforest. However, this system passed through dramatic changes in the last centuries that affected the quality of this environment. The opening of an artificial channel (Valo Grande Channel), in Iguape in the 19th century, diverted about $70 \%$ of the waters of the Ribeira de Iguape River to inside the estuarine system (Mahiques et al., 2013). This river housed several mines of $\mathrm{Pb}, \mathrm{Zn}, \mathrm{Au}$ and $\mathrm{Ag}$, that operated dumping tailing and metallurgical slags of blast furnace directly into the river until 1995, contaminating the water and the sediments along its course and part of the estuary, especially with $\mathrm{Pb}$ (Guimarães \& Sígolo, 2008; Mahiques et al., 2013). After the closure of the mines the residues were deposited on the riverbanks, exposed to the weathering and consequently to lixiviation (Guimarães \& Sígolo, 2008).

Over the years the concentrations of $\mathrm{Pb}$ in the sediments and in the water have decreased considerably (Mahiques et al., 2013; Abessa et al., 2014), however the system remains weakened by the load of mining residues received. The metals suffer mobility along the drainage course of the river and in the estuarine system through suspended solids, being bioavailable and assimilated by the local biota (Guimarães \& Sígolo, 2008; Rodrigues et al., 2012; Choueri, 2015). This fact allows the accumulation of metals in high concentrations in animals of higher levels of the food chain, as marine mammals.

Despite of the growing number of studies with contaminants in marine mammals in Brazil, little is known about the health of these animals and how much chemical contamination is affecting the many populations of cetaceans that occur in these waters (Siciliano et al., 2005; Lemos et al., 2013; Moura et al., 2014). The Sotalia guianensis conservation status is defined as "data deficient" in both the National Action Plan for the Conservation of Aquatic Mammals of ICMBio (2011) and the IUCN (2018), therefore, more research is necessary. Quantifying the levels of metals in the species can help to diagnose the impact of their habitat over different populations and to maintain assistance in developing strategies for the conservation of these dolphins on the Brazilian coast (Lemos et al., 2013).

This study aimed to determine the concentrations of $\mathrm{Fe}, \mathrm{Zn}$, $\mathrm{Mn}, \mathrm{Cr}, \mathrm{Cu}, \mathrm{Co}, \mathrm{Pb}$ and $\mathrm{Ni}$ in liver samples of Guiana dolphins of the Estuarine-Lagoon Complex of Iguape-Cananéia and verify if these concentrations differ between the sexes and age classes. These results were compared to the literature of the same species from other geographical areas to evaluate the environmental quality of their habitat and increase the knowledge about the Guiana dolphin on Brazilian waters.

\section{MATERIALS AND METHODS}

\section{Study area}

The Estuarine-Lagoon Complex of Iguape-Cananéia (Figure 1) is located in the south of the São Paulo State, southeastern Brazil. It corresponds to a system formed by four large islands (Cardoso, Cananéia, Comprida and Iguape), located between latitudes of $24^{\circ} 50^{\prime}$ to $25^{\circ} 10^{\prime} \mathrm{S}$ and longitudes of $47^{\circ} 25^{\prime}$ to $48^{\circ} 00^{`} \mathrm{~W}$ (Tessler \& Souza, 1998).

\section{Sampling}

Samples were obtained from stranded dead Guiana dolphins on the beaches of that region between 2009 and 2012, through the beaches monitoring program of the Instituto de Pesquisas Cananéia - IPeC (SISBio License No. 22840- 


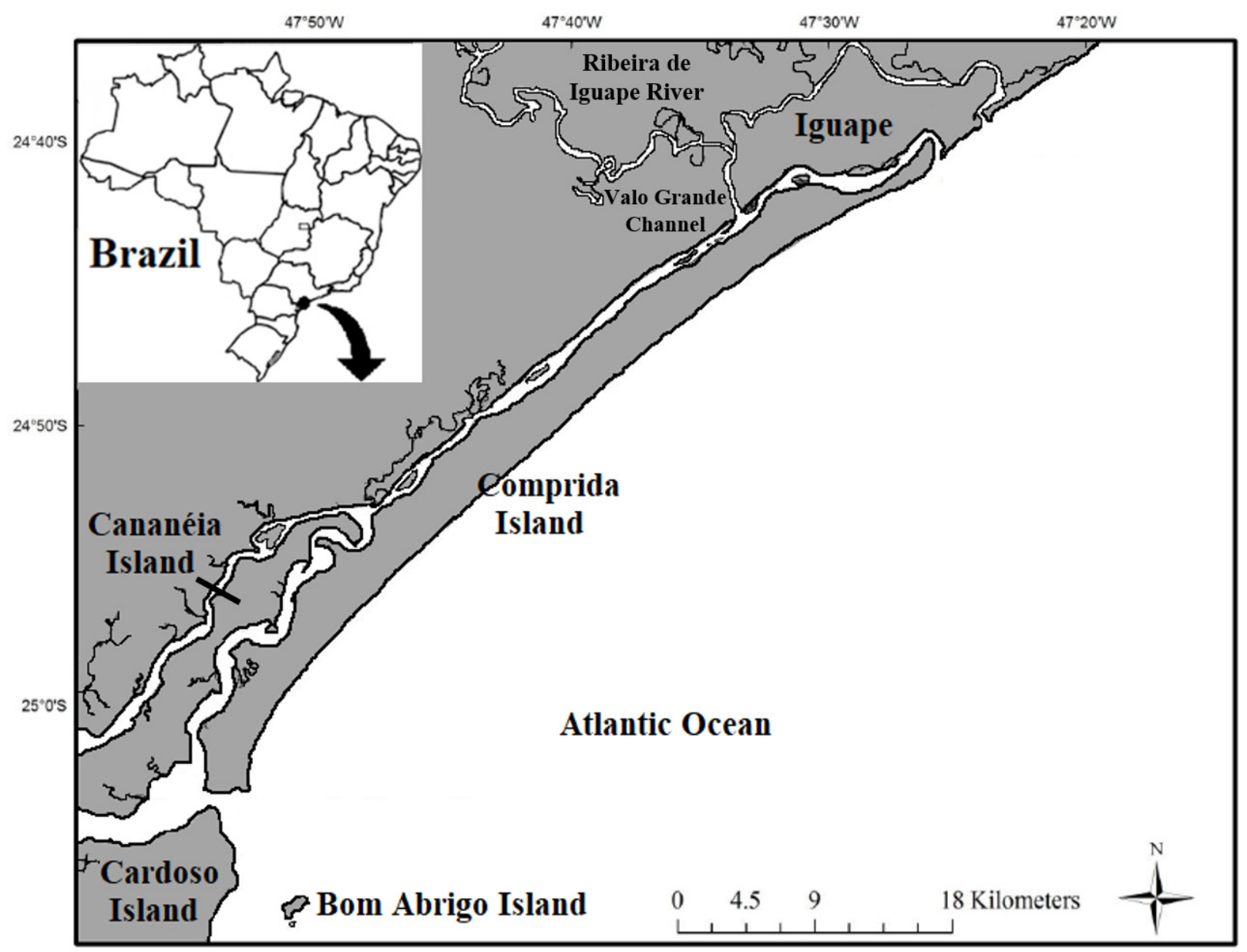

Figure 1. Map of the Estuarine-Lagoon Complex of Iguape-Cananéia and its location in Brazil.

3). Twenty-one animals, being six males, thirteen females and two unidentified, were analyzed. Biometrics and macroscopic evaluation was held to assess the conditions of the carcasses and to identify their sex and the age class, when possible. Information about the age of the animals were not available so the age classes were arbitrarily estimated according to the length of the animals. Animals of a length varying between 90 and $100 \mathrm{~cm}$ were classified as infants; animals between 111 and $165 \mathrm{~cm}$ as juveniles; and animals longer than $165 \mathrm{~cm}$ as adults, adapting to the species' propositions made by Rosas $\&$ Monteiro-Filho (2002). Samples of the liver were collected from fresh carcasses (code 2) or when in early decomposition phase (code 3), according to the classification recommended by Geraci \& Lounsbury (1993). The necropsy of the animals was held following the conduct protocol of the Rede de Encalhe de Mamíferos Aquáticos do Nordeste - REMANE (IBAMA, 2005). Approximately 20 grams of the hepatic tissue was removed using a stainless-steel scalpel, stored in plastic containers and frozen at $-20^{\circ} \mathrm{C}$ until analysis.

\section{Analytical procedures}

Analytical procedures were held in the Laboratório de Estudos Avançados em Química Ambiental - LEAQUA in the Universidade Tecnológica Federal do Paraná - UTFPR. Analytical procedures has followed one of the methods presented by Más-Rosa (2009), with some adaptations, in which the samples were homogenized by maceration and divided into triplicates of approximately $5 \mathrm{~g}$ (wet weight). Acid digestion was performed with $30 \mathrm{ml}$ of aqueous solution of $\mathrm{HNO}_{3} 1: 1$ under reflux on a heating plate at $95^{\circ} \mathrm{C}$ for 12 hours until complete oxidation, evidenced by limpid extract. Next, the samples were reduced to an equivalent volume of $5 \mathrm{~mL}$ on the heating plate. After cooling, the samples were filtered and had their volume gauged to $50 \mathrm{~mL}$ with deionized water. All the reagents used were of an analytic degree and the materials used during the procedures were previously decontaminated by washing with neutral detergent and by bathing in a solution of nitric acid (10\%) for $24 \mathrm{~h}$.

The quantification of $\mathrm{Fe}, \mathrm{Zn}, \mathrm{Mg}, \mathrm{Cr}, \mathrm{Cu}, \mathrm{Co}, \mathrm{Pb}$ and $\mathrm{Ni}$ was done by Flame Atomic Absorption Spectrometry (FAAS) model GBC, Avanta, respecting the prepositions of the method to the different metals (Table 1). Standard curves were prepared with successive dilutions using a stock solution of each metal of analytical grade $\left(1.000 \mathrm{mg} \mathrm{L}^{-1}\right)$ Merck. The quality of the results was accompanied with the use of an analytical blank and the determination performed in triplicates. Due to the lack of certified reference material (CRM) of aquatic mammal 
Table 1. Linear correlation coefficient $\left(\mathrm{r}^{2}\right)$, limits of detection (LOD) and limits of quantification (LOQ) for the studied metals.

\begin{tabular}{cccc}
\hline Metals & $\mathrm{r}^{2}$ & LOD $\left(\mu \mathrm{g} \mathrm{L}^{-1}\right)$ & LOQ $\left(\mu \mathrm{g} \mathrm{L}^{-1}\right)$ \\
\hline $\mathrm{Fe}$ & 0.9997 & 5 & 15 \\
$\mathrm{Zn}$ & 0.9995 & 3 & 10 \\
$\mathrm{Mn}$ & 0.9954 & 6 & 18 \\
$\mathrm{Co}$ & 0.9985 & 4 & 15 \\
$\mathrm{Cu}$ & 0.9963 & 4 & 13 \\
$\mathrm{Cr}$ & 0.9896 & 5 & 16 \\
$\mathrm{~Pb}$ & 0.9954 & 5 & 16 \\
$\mathrm{Ni}$ & 0.9979 & 2 & 6 \\
\hline
\end{tabular}

tissues, the exactitude of the method was verified by addition and recovery tests performed in fish tissues, used to guarantee the internal standards in the laboratory. Recovery rates ranged from $82 \%$ to $108 \%$ in all investigations. Metal concentrations were expressed in $\mu \mathrm{g} \mathrm{g}^{-1}$ wet weight.

\section{Statistical analysis}

Statistical analyses were conducted to verify if the mean concentrations of the metals in liver differ between the sexes and the age classes. The normality test Shapiro Wilk was applied, followed by the homogeneity test of Levene. For data with normal distribution ANOVA test was used. For data with no normal distribution the non-parametric test Kruskal-Wallis was applied. The level of statistical significance was defined at $\mathrm{p}<0.05$.

\section{RESULTS}

Biological data of sampled animals are shown in Table 2. The concentrations of the metals in the liver of each analyzed animal (in $\mu \mathrm{g} \mathrm{g}^{-1}$ wet weight) are shown in Table 3. Mean concentrations of the metals in liver (in $\mu \mathrm{g} \mathrm{g}^{-1}$ wet weight) were obtained in the following order of magnitude: $\mathrm{Fe}>\mathrm{Zn}>\mathrm{Cu}>\mathrm{Mn}>\mathrm{Pb}>\mathrm{Cr}>\mathrm{Co}>\mathrm{Ni}$ (Figure 2).

The iron and zinc had the highest mean concentrations in livers, with values of 124.82 and $41.52 \mu \mathrm{g} \mathrm{g}^{-1}$, respectively. The

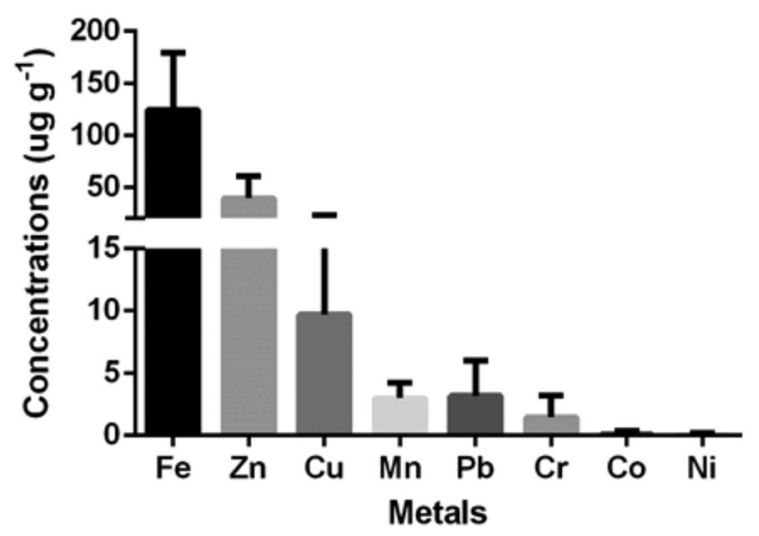

Figure 2. Mean concentrations and standard deviation of the metals Fe, $\mathrm{Zn}$, $\mathrm{Cu}, \mathrm{Mn}, \mathrm{Pb}, \mathrm{Cr}, \mathrm{Co}$ and $\mathrm{Ni}$ in liver of Sotalia guianensis from the EstuarineLagoon Complex of Iguape-Cananéia (in $\mathrm{mg} \mathrm{g}^{-1}$ wet weight). variations in livers (minimum and maximum values among the animals) ranged from 55.28 to $233.51 \mu \mathrm{g} \mathrm{g}^{-1}$ for iron and from $25.76 \mu \mathrm{g} \mathrm{g}^{-1}$ to $100.75 \mu \mathrm{g} \mathrm{g}^{-1}$ for zinc. There was no influence of the gender $\left(\mathrm{Fe}: \mathrm{r}^{2}=0.1782 ; \mathrm{F}_{1: 17}=3.03 ; \mathrm{p}=0.0998 ; \mathrm{Zn}: \chi^{2}=\right.$ $0.0692 ; \mathrm{df}=1 ; \mathrm{p}=0.7925)$, nor the age classes $\left(\mathrm{Fe}: \mathrm{r}^{2}=0.5269\right.$; $\left.\mathrm{F}_{2: 18}=0.50 ; \mathrm{p}=0.6144 ; \mathrm{Zn}: \chi^{2}=4.530 ; \mathrm{df}=2 ; \mathrm{p}>0.0987\right)$ in the livers concentrations for both metals.

The concentration of copper varied from 1.28 to 52.08 $\mu \mathrm{g} \mathrm{g}^{-1}$, with a mean value of $9.71 \mu \mathrm{g} \mathrm{g}^{-1}$ among the animals. The accumulations between the sexes were also similar $\left(\chi^{2}\right.$ $=1.6187 ; \mathrm{df}=1 ; \mathrm{p}=0.2033)$, while infants showed higher concentrations of the metal in the liver $\left(\chi^{2}=5.499 ; \mathrm{df}=2 ; \mathrm{p}\right.$ $=0.0533$ ).

For manganese, the mean concentration obtained was of $3.00 \mu \mathrm{g} \mathrm{g}^{-1}$, varying from 0.73 to $5.55 \mu \mathrm{g} \mathrm{g}^{-1}$. For this metal, no differences in the accumulation between the sexes $\left(\mathrm{r}^{2}=\right.$ $\left.0.1205 ; \mathrm{F}_{1.17}=2.04 ; \mathrm{p}=0.17\right)$ and the age classes $\left(\mathrm{r}^{2}=0.2858\right.$; $\mathrm{F}_{2: 18}=3.60 ; \mathrm{p}=0.0483$ ) were observed.

For lead, a mean concentration of $3.17 \mu \mathrm{g} \mathrm{g}^{-1}$, varying from lower than the limit of quantification $(<\mathrm{LOQ})$ to $9.62 \mu \mathrm{g} \mathrm{g}^{-1}$ was found. This is the highest mean concentration and variation observed for the species in the Brazilian coast compared to the previous studies (Table 3), showing some concern from the toxicology point of view. There was no influence of the

Table 2. Data about Sotalia guianensis sampled from August 2009 to July 2012 in the Estuarine-Lagoon Complex of Iguape-Cananéia.

\begin{tabular}{|c|c|c|c|c|c|}
\hline Sample ID & Date & Sex & $\begin{array}{l}\text { Body length } \\
\quad(\mathrm{cm})\end{array}$ & $\begin{array}{l}\text { Age } \\
\text { Class }\end{array}$ & $\begin{array}{c}\text { Conditional } \\
\text { phase } \\
\text { of the } \\
\text { carcasses }\end{array}$ \\
\hline Sg01 & $2009 / 08 / 30$ & n.a. & 96 & Infant & 3 \\
\hline $\mathrm{Sg} 02$ & $2009 / 09 / 10$ & M & 208 & Adult & 3 \\
\hline $\mathrm{Sg} 03$ & $2010 / 01 / 09$ & $\mathrm{~F}$ & 169 & Adult & 3 \\
\hline $\mathrm{Sg04}$ & $2010 / 02 / 19$ & $\mathrm{~F}$ & 149 & Juvenile & 3 \\
\hline $\mathrm{Sg} 05$ & $2010 / 03 / 29$ & $\mathrm{~F}$ & 198 & Adult & 3 \\
\hline $\mathrm{Sg} 06$ & $2010 / 05 / 23$ & $\mathrm{~F}$ & 204 & Adult & 3 \\
\hline $\mathrm{Sg} 07$ & $2011 / 01 / 09$ & M & 155 & Juvenile & 2 \\
\hline $\mathrm{Sg} 08$ & $2011 / 03 / 20$ & $\mathrm{~F}$ & 198 & Adult & 2 \\
\hline $\mathrm{Sg} 09$ & $2011 / 03 / 30$ & M & 164 & Juvenile & 3 \\
\hline $\operatorname{Sg} 10$ & $2011 / 04 / 15$ & $\mathrm{~F}$ & 195 & Adult & 2 \\
\hline Sg11 & $2011 / 05 / 11$ & $\mathrm{~F}$ & 208 & Adult & 2 \\
\hline $\mathrm{Sg} 12$ & $2011 / 08 / 08$ & $\mathrm{~F}$ & 177 & Adult & 3 \\
\hline Sg13 & $2011 / 08 / 26$ & $\mathrm{~F}$ & 201 & Adult & 3 \\
\hline Sg14 & $2011 / 09 / 02$ & $\mathrm{~F}$ & 98 & Infant & 3 \\
\hline $\operatorname{Sg} 15$ & $2011 / 09 / 13$ & n.a. & 99 & Infant & 3 \\
\hline $\operatorname{Sg} 16$ & $2011 / 09 / 22$ & $\mathrm{~F}$ & 208 & Adult & 2 \\
\hline $\operatorname{Sg} 17$ & $2011 / 10 / 07$ & $\mathrm{~F}$ & 185 & Adult & 2 \\
\hline $\operatorname{Sg} 18$ & $2011 / 10 / 27$ & $\mathrm{~F}$ & 198 & Adult & 2 \\
\hline Sg19 & $2012 / 05 / 11$ & M & 205 & Adult & 2 \\
\hline $\mathrm{Sg} 20$ & $2012 / 06 / 14$ & M & 189 & Adult & 2 \\
\hline $\mathrm{Sg} 21$ & $2012 / 07 / 07$ & M & 195 & Adult & 3 \\
\hline
\end{tabular}

n.a., Data not available.

* Conditional phase of the carcasses: Code 1 - Live stranded animals. Code 2 - Fresh carcass

Code 3 - Carcasses in early phases of decomposition. Code 4 - Carcasses at advanced phases of decomposition. Code 5 - Mummified carcasses or skeletal remains (Geraci \& Lounsbury, 1993). 
Table 3. Concentrations of the studied metals (in $\mu \mathrm{g} \mathrm{g}^{-1}$ ) in Sotalia guianensis sampled from August 2009 to July 2012 in the Estuarine-Lagoon Complex of Iguape-Cananéia.

\begin{tabular}{|c|c|c|c|c|c|c|c|c|}
\hline Sample ID & $\mathrm{Fe}$ & $\mathrm{Zn}$ & $\mathrm{Cu}$ & $\mathrm{Mn}$ & $\mathrm{Pb}$ & $\mathrm{Cr}$ & $\mathrm{Co}$ & $\mathrm{Ni}$ \\
\hline $\mathrm{Sg} 01$ & 105.10 & 78.03 & 6.12 & 5.55 & 6.03 & $<\mathrm{LOQ}$ & 0.17 & 0.26 \\
\hline $\mathrm{Sg} 02$ & 61.76 & 29.54 & 3.83 & 2.81 & $<$ LOQ & $<\mathrm{LOQ}$ & $<\mathrm{LOQ}$ & $<\mathrm{LOQ}$ \\
\hline $\mathrm{Sg} 03$ & 55.28 & 26.79 & 5.87 & 2.54 & 5.42 & $<\mathrm{LOQ}$ & $<\mathrm{LOQ}$ & $<\mathrm{LOQ}$ \\
\hline $\mathrm{Sg} 04$ & 162.59 & 100.75 & 15.46 & 4.16 & 3.82 & 1.88 & 0.93 & $<\mathrm{LOQ}$ \\
\hline Sg05 & 203.87 & 35.81 & 6.72 & 2.60 & 1.22 & 0.37 & $<\mathrm{LOQ}$ & 0.43 \\
\hline $\mathrm{Sg} 06$ & 175.20 & 28.10 & 6.28 & 2.11 & 8.93 & 0.71 & 0.88 & $<\mathrm{LOQ}$ \\
\hline Sg07 & 75.55 & 63.61 & 6.76 & 4.03 & 7.15 & $<\mathrm{LOQ}$ & $<\mathrm{LOQ}$ & $<\mathrm{LOQ}$ \\
\hline $\mathrm{Sg} 08$ & 233.51 & 33.48 & 9.69 & 2.91 & 3.91 & $<\mathrm{LOQ}$ & $<\mathrm{LOQ}$ & $<\mathrm{LOQ}$ \\
\hline Sg09 & 101.65 & 32.91 & 4.20 & 2.98 & 9.62 & $<\mathrm{LOQ}$ & $<\mathrm{LOQ}$ & $<\mathrm{LOQ}$ \\
\hline $\operatorname{Sg} 10$ & 85.83 & 33.90 & 4.08 & 1.59 & 1.15 & 3.09 & $<\mathrm{LOQ}$ & $<\mathrm{LOQ}$ \\
\hline $\mathrm{Sg} 11$ & 184.09 & 29.11 & 6.31 & 1.70 & 1.46 & 3.08 & $<\mathrm{LOQ}$ & $<\mathrm{LOQ}$ \\
\hline Sg12 & 183.86 & 56.81 & 4.37 & 3.95 & $<\mathrm{LOQ}$ & 4.55 & $<\mathrm{LOQ}$ & $<\mathrm{LOQ}$ \\
\hline $\operatorname{Sg} 13$ & 75.00 & 25.76 & 3.62 & 3.32 & 0.88 & 4.77 & $<\mathrm{LOQ}$ & $<\mathrm{LOQ}$ \\
\hline $\mathrm{Sg} 14$ & 98.55 & 48.08 & 52.08 & 3.53 & 0.80 & 2.23 & $<\mathrm{LOQ}$ & $<\mathrm{LOQ}$ \\
\hline Sg15 & 92.30 & 44.55 & 43.59 & 3.64 & 1.09 & 2.33 & 0.27 & $<\mathrm{LOQ}$ \\
\hline $\mathrm{Sg} 16$ & 201.05 & 26.70 & 7.08 & 2.02 & 0.99 & 4.92 & 0.08 & $<\mathrm{LOQ}$ \\
\hline $\operatorname{Sg} 17$ & 72.62 & 25.64 & 1.28 & 0.73 & 2.93 & $<\mathrm{LOQ}$ & $<\mathrm{LOQ}$ & $<\mathrm{LOQ}$ \\
\hline $\operatorname{Sg} 18$ & 120.59 & 30.51 & 4.20 & 2.52 & 4.70 & 2.15 & 0.07 & $<\mathrm{LOQ}$ \\
\hline Sg19 & 72.16 & 50.05 & 4.55 & 5.54 & 2.76 & 0.12 & 0.21 & $<\mathrm{LOQ}$ \\
\hline Sg20 & 139.26 & 42.10 & 3.53 & 2.97 & 1.64 & $<\mathrm{LOQ}$ & $<\mathrm{LOQ}$ & $<\mathrm{LOQ}$ \\
\hline Sg21 & 121.38 & 29.72 & 4.36 & 1.89 & 2.01 & 0.49 & 0.14 & 0.48 \\
\hline
\end{tabular}

$<$ LOQ - Lower than the limit of quantification.

gender in the concentrations found in the livers $\left(\chi^{2}=0.4330\right.$; $\mathrm{df}=1 ; \mathrm{p}=0.5105)$, nor the age classes $\left(\chi^{2}=4.522 ; \mathrm{df}=2 ; \mathrm{p}\right.$ $=0.1015$ ).

Chromium concentrations varied from $<\mathrm{LOQ}$ to 4.77 $\mu \mathrm{g} \mathrm{g}{ }^{-1}$, with a mean value of $1.46 \mu \mathrm{g} \mathrm{g}^{-1 .}$ The accumulations between the sexes $\left(\chi^{2}=5.4686 ; \mathrm{df}=1 ; \mathrm{p}=0.0193\right)$ and age classes $\left(\chi^{2}=1.298 ; \mathrm{df}=2 ; \mathrm{p}=0.5513\right)$ were similar for this metal.

For cobalt and nickel the results varied from $<\mathrm{LOQ}$ to 0.93 $\mu \mathrm{g} \mathrm{g}^{-1}$ and $<$ LOQ to $0.48 \mu \mathrm{g} \mathrm{g}^{-1}$, with a mean concentration of $0.13 \mu \mathrm{g} \mathrm{g}^{-1}$ and $0.06 \mu \mathrm{g} \mathrm{g}^{-1}$, respectively. The concentrations of these metals in the liver were similar between the sexes (Co: $\chi^{2}=0.0113 ; \mathrm{df}=1 ; \mathrm{p}=0.9153 ; \mathrm{Ni}: \chi^{2}=0.4340 ; \mathrm{df}=1 ; \mathrm{p}=$ $0.5105)$ and the age classes $\left(\mathrm{Co}: \chi^{2}=1.506 ; \mathrm{df}=2 ; \mathrm{p}=0.5961\right.$; $\left.\mathrm{Ni}: \chi^{2}=1.058 ; \mathrm{df}=2 ; \mathrm{p}=0.9999\right)$.

\section{DISCUSSION}

Table 4 shows a comparison among the mean values \pm standard deviation (SD) of the concentrations for the studied metals in livers and the variation of the means (minimum and maximum values) found in this and in other studies with the species on the Brazilian coast.

The concentrations obtained for $\mathrm{Fe}, \mathrm{Zn}, \mathrm{Cu}, \mathrm{Mn}, \mathrm{Cr}$, $\mathrm{Co}$ and $\mathrm{Ni}$, compared with the literature, were in the same order of variation described before for the species (Table 3). In general, the concentrations of these essential metals are expected to be regulated (Law et al., 1991).

In marine species, higher concentrations of $\mathrm{Fe}$ and $\mathrm{Zn}$ in the liver, compared with other metals, occur due to its abundance in the environment and to the fact that these metals actively participate in the metabolism (O'Shea, 1999; Kunito et al., 2004). However, environmental contamination may increase the bioavailability, and consequently the absorption and the accumulation of these elements. This situation was observed in the north coast of Rio de Janeiro State by Lemos et al. (2013), where high $\mathrm{Zn}$ levels in the livers of the animals were related to local contamination. Although the studied area was affected by ancient mining activities, that also enriched the estuary with Zn (Guimarães \& Sígolo, 2008; Mahiques et al., 2013), the concentrations found by this research were lower than the ones described by Lemos et al. (2013), suggesting that it is not a concern for the species in the area.

The higher $\mathrm{Cu}$ concentrations observed in the liver of infant animals corroborate with the study made by Más-Rosa (2009) in the coast of Bahia State, which also found higher concentrations of this metal in infants. Kunito et al. (2004) also found high concentrations of $\mathrm{Cu}$ in the liver of animals of this same species under the age of one year. This may be for the fact that newborns have a specific requirement for the metal, and present lower excretion rate (Caurant et al., 1994). Moreover, the liver can act as a storage for this element in a period of rapidly postnatal growth (Mason et al., 1980), and elevated concentrations of $\mathrm{Cu}$ in neonates and infants of marine mammals have been extensively observed (Caurant et al., 1994; Law et al., 1991; Kunito et al., 2004; Bilandžić et al., 2016).

The concentrations of $\mathrm{Mn}$ resembled the one found by Lemos et al. (2013), also in wet weight samples. Nevertheless, the $\mathrm{Mn}$ was the element detected in higher concentrations in the liver when analyzed by dry weight in the same study (Lemos et al., 2013), being similar to the concentrations found by Kunito et al. (2004) and Más-Rosa (2009).

The evaluation of $\mathrm{Cr}$, $\mathrm{Co}$ and $\mathrm{Ni}$ in cetacean tissues are rather scarce and there are few data in the literature for the Guiana dolphin. Generally, the concentrations of these metals in the liver of dolphins are low, and in some cases, it does not overcome the limits of quantification of the method (Das et al., 2000; Kunito et al., 2004), as observed in this study. The variation of the $\mathrm{Cr}$ concentrations was similar to the variation presented by Kunito et al. (2004) in animals of the coast of Paraná and São Paulo states. For Ni, the values found were similar to those presented by Más-Rosa (2009) in the study on the coast of Bahia State. For Co, the concentrations were similar to both studies (Kunito et al., 2004; Más-Rosa, 2009).

In general, variations of concentrations among the studies are common and expected as a result of the various factors that affect the accumulation of metals in marine mammals and the techniques applied to the studies. However, the variations presented in this study, combined with the other values reported in the literature, can represent general guides for the accumulation of these metals for the species in the Brazilian coast, reflecting its metabolic needs and exposure.

Nonetheless, two important points must be considered. The presented data came from stranded animals, therefore, not necessarily representatives of healthy conditions. In addition, 
Table 4. Comparison of the concentrations of metals (mean $\pm \mathrm{SD}$ in $\mu \mathrm{g} \mathrm{g}^{-1}$ ) in livers of Sotalia guianensis obtained in this study with the Brazilian literature for the species.

\begin{tabular}{|c|c|c|c|c|c|}
\hline Metal & $\begin{array}{c}\text { Measurement } \\
\text { weight }\end{array}$ & $\begin{array}{c}\text { Mean concentration } \\
+\mathrm{SD} \\
\left(\mathrm{mg} \mathrm{g}^{-1}\right)\end{array}$ & $\begin{array}{l}\text { Variation } \\
\text { Min-Max } \\
\left(\mathrm{mg} \mathrm{g}^{-1}\right) \\
\end{array}$ & Site & Reference \\
\hline \multirow[t]{3}{*}{$\mathrm{Fe}$} & Wet weight & $124.82 \pm 54.07$ & $55.28-233.51$ & SP - Brazil & This study \\
\hline & Dry weight & - & $567-879$ & BA - Brazil & Más-Rosa, 2009 \\
\hline & Dry weight & $794 \pm 370$ & $330-1470$ & SP/PR - Brazil & Kunito et al., 2004 \\
\hline \multirow[t]{6}{*}{ Zn } & Wet weight & $41.52 \pm 19.48$ & $25.76-100.75$ & SP - Brazil & This study \\
\hline & Wet weight & $65.85 \pm 51.11$ & $26.20-209.3$ & $\mathrm{RJ}$ - Brazil & Lemos et al., 2013 \\
\hline & Dry weight & $192.6 \pm 124.1$ & $96.74-530.8$ & RJ - Brazil & Lemos et al., 2013 \\
\hline & Dry weight & - & $161-255$ & BA - Brazil & Más-Rosa, 2009 \\
\hline & Wet weight & 85.40 & $65.90-107$ & $\mathrm{RJ}$ - Brazil & Carvalho et al., 2008 \\
\hline & Dry weight & $192 \pm 76$ & $117-348$ & SP/PR - Brazil & Kunito et al., 2004 \\
\hline \multirow[t]{6}{*}{$\mathrm{Cu}$} & Wet weight & $9.71 \pm 13.05$ & $1.28-52.08$ & SP - Brazil & This study \\
\hline & Wet weight & $8.120 \pm 4.6$ & $1.180-18.03$ & RJ - Brazil & Lemos et al., 2013 \\
\hline & Dry weight & $23.66 \pm 11.13$ & $4.880-46.05$ & RJ - Brazil & Lemos et al., 2013 \\
\hline & Dry weight & - & $18.2-50.1$ & BA - Brazil & Más-Rosa, 2009 \\
\hline & Dry weight & $26.48 \pm 19.89$ & $13.44-83.77$ & RJ - Brazil & Seixas et al., 2009 \\
\hline & Dry weight & $157 \pm 436$ & $14.5-1970$ & SP/PR - Brazil & Kunito et al., 2004 \\
\hline \multirow[t]{5}{*}{ Mn } & Wet weight & $3.00 \pm 1.21$ & $0.73-5.55$ & SP - Brazil & This study \\
\hline & Wet weight & $2.51 \pm 1.13$ & $0.66-5.11$ & $\mathrm{RJ}$ - Brazil & Lemos et al., 2013 \\
\hline & Dry weight & $7.34 \pm 2.53$ & $2.73-13.05$ & $\mathrm{RJ}$ - Brazil & Lemos et al., 2013 \\
\hline & Dry weight & - & $8.64-13.7$ & BA - Brazil & Más-Rosa, 2009 \\
\hline & Dry weight & $9.84 \pm 2.75$ & $5.91-15.1$ & $\mathrm{SP} / \mathrm{PR}$ - Brazil & Kunito et al., 2004 \\
\hline \multirow[t]{6}{*}{$\mathbf{P b}$} & Wet weight & $3.17 \pm 2.84$ & $<\mathrm{LOQ}-9.62$ & SP - Brazil & This study \\
\hline & Dry weight & - & $0.040-0.3$ & BA - Brazil & Korn et al., 2010 \\
\hline & Dry weight & $<$ LOQ & $<$ LOQ & BA - Brazil & Más-Rosa, 2009 \\
\hline & Dry weight & $1.55 \pm 0.75$ & $0.74-2.73$ & RJ - Brazil & Seixas et al., 2009 \\
\hline & Dry weight & $0.063 \pm 0.06$ & $0.028-0.197$ & SP/PR - Brazil & Kunito et al., 2004 \\
\hline & Dry weight & $0.11 \pm 0.02$ & $0.10-0.12$ & CE - Brazil & Monteiro-Neto et al., 2003 \\
\hline \multirow[t]{3}{*}{$\mathrm{Cr}$} & Wet weight & $1.46 \pm 1.75$ & $<\mathrm{LOQ}-4.77$ & SP - Brazil & This study \\
\hline & Dry weight & - & $0.49-0.68$ & BA - Brazil & Más-Rosa, 2009 \\
\hline & Dry weight & $0.93 \pm 1.29$ & $0.26-5.1$ & SP/PR - Brazil & Kunito et al., 2004 \\
\hline \multirow[t]{3}{*}{ Co } & Wet weight & $0.13 \pm 0.26$ & $<\mathrm{LOQ}-0.93$ & SP - Brazil & This study \\
\hline & Dry weight & $<$ LOQ & $<$ LOQ & BA - Brazil & Más-Rosa, 2009 \\
\hline & Dry weight & $0.027 \pm 0.012$ & $0,016-0.051$ & SP/PR - Brazil & Kunito et al., 2004 \\
\hline \multirow[t]{2}{*}{$\mathbf{N i}$} & Wet weight & $0.06 \pm 0.14$ & $<\mathrm{LOQ}-0.48$ & SP - Brazil & This study \\
\hline & Dry weight & - & $<\mathrm{LOQ}-0.30$ & BA - Brazil & Más-Rosa, 2009 \\
\hline
\end{tabular}

$<$ LOQ - Lower than the limit of quantification. 
the sampling is conducted in unknown postmortem time and some metal loss may occur. Moreover, this species is highly captured by fisheries in the Cananéia region (Zappes et al., 2009), and some of the individuals analyzed in this study may be from incidental capture, there so being healthy animals.

Differently from the other studied metals, $\mathrm{Pb}$ has a high toxic potential. This metal is not distributed homogeneously throughout the body. $\mathrm{As} \mathrm{Pb}$ is qualitatively a biological analogue of calcium (Moreira \& Moreira, 2004), the highest accumulation of $\mathrm{Pb}$ in aquatic mammals occurs in hard tissues, as bones and teeth (O'Shea, 1999; O'Hara \& O'Shea, 2001; Das et al., 2000, Caurant et al., 2006). In general, the $\mathrm{Pb}$ concentrations found in soft tissues are often lower than 1 $\mu \mathrm{g} \mathrm{g} \mathrm{g}^{-1}$ (O'Hara \& O'Shea, 2001; Caurant et al., 2006). In this research, the highest mean concentration of $\mathrm{Pb}$ in the liver for the species was described $\left(3.17 \mu \mathrm{g} \mathrm{g}^{-1}\right)$ arousing some concern and indicating that $\mathrm{Pb}$ concentrations in bones or teeth of the analyzed individuals could have been even higher.

Among the animals, six specimens $(\mathrm{Sg} 01, \mathrm{Sg} 03, \mathrm{Sg} 06$, $\mathrm{Sg} 07, \mathrm{Sg} 09$, and $\mathrm{Sg} 18$ ) had elevated mean concentrations exceeding $4 \mu \mathrm{g} \mathrm{g}^{-1}$ of $\mathrm{Pb}$ in the liver (Table 4). These animals form a heterogenic group that contemplates both sex and different age classes. The specimen $\mathrm{Sg} 01$ was an infant that had a $6.03 \mu \mathrm{g} \mathrm{g}^{-1} \mathrm{~Pb}$ mean concentration in the liver. The specimens $\mathrm{Sg} 07$ and $\mathrm{Sg} 09$ were juvenile males, which had mean concentrations of $7.15 \mu \mathrm{g} \mathrm{g}^{-1}$ and $9.62 \mu \mathrm{g} \mathrm{g}^{-1}$ of $\mathrm{Pb}$ in the liver, respectively. This last one being the most elevated mean concentration of the metal among the studied animals. The specimens $\mathrm{Sg} 03, \mathrm{Sg} 06$ and $\mathrm{Sg} 18$ were adult females that had mean concentrations of $5.42 \mu \mathrm{g} \mathrm{g}^{-1}, 8.93 \mu \mathrm{g} \mathrm{g}^{-1}$ and $4.70 \mu \mathrm{g}$ $\mathrm{g}^{-1}$ of $\mathrm{Pb}$ in the liver, respectively. The female Sg18 had been producing milk, which indicates that it was probably nursing an infant from a recent pregnancy. Due to the limitations imposed by the lack of available information, a profound analysis could not be held in these animals.

In order to understand these elevated accumulations, the bioavailability of the element in the environment must be observed, as the concentrations of non-essential metals are expected to be high only in cases of exposure to environmental contamination. In these cases, the eating habits of the species and the complexity of the food chain are also important, once the primary route of exposure to metals is through the feeding (Law et al., 1991; Das et al., 2000).

Regarding theses aspects, the local history and previous studies elucidate the bioavailability of the element in the area. The contamination of the sediments of the Ribeira de Iguape River and of the northern and central part of the EstuarineLagoon Complex of Iguape-Cananéia by lead caused by ancient mining activities may have decreased over the years (Guimarães \& Sígolo, 2008; Mahiques et al., 2013; Abessa et al., 2014). However, the metal is still bioavailable through the suspended solids being assimilated by the local biota, with the elevated accumulation of the metal reported in the tissues of different species of mollusks of the Ribeira de Iguape River (Guimarães \& Sígolo, 2008; Rodrigues et al., 2012) and in fishes from the estuarine region (Choueri, 2015).
This direct measurement of the bioavailability of $\mathrm{Pb}$ in the liver of the dolphins suggests the trophic transfer of the metal. Their exposition through the animals of lower trophic levels, as mollusks and fishes, would allow the biomagnification of lead in higher trophic levels and may be reflected in the concentrations found in the liver of the Guiana dolphins. As so, indicating that the contamination of the aquatic food chain in the studied area, may be of concern for the health of this small dolphin population and for the local human population on the consumption of aquatic organisms.

Previous investigations demonstrate the influence of the environmental contamination on the exposition of dolphins to $\mathrm{Pb}$, and the importance to investigate their habitat conditions. Law et al. $(1991 ; 1992)$ found high concentrations of this metal, up to $7 \mu \mathrm{g} \mathrm{g}^{-1}$ in the liver of dolphins, and the author evidenced that these higher concentrations of $\mathrm{Pb}$ were observed in the animals that live close to anthropogenic sources. Kemper et al. (1994) reported the highest concentration of $\mathrm{Pb}$, in the amount of $62 \mu \mathrm{g} \mathrm{g}^{-1}$, in bones of an infant bottlenose dolphin (Tursiops truncatus) stranded dead near a lead smelter in the Australian coast.

However, it is still necessary to evaluate how physiological parameters and the environmental conditions interfere in the process of bioaccumulation, since the total amount of these elements in the liver does not provide enough information about the origin of the contamination and the toxicity of the analyzed samples.

The very wide variation of $\mathrm{Pb}$ concentrations in the analyzed animals $\left(<\mathrm{LOQ}-9.62 \mu \mathrm{g} \mathrm{g}^{-1}\right)$, suggests that the eating habits of the species also may affect the intake of the metal. The Guiana dolphin has most of its diet based on teleost fish, displaying different proportions of items and different prey items according to the location and the availability of food (Cremer et al., 2012). This may affect the exposure of $\mathrm{Pb}$ of each animal individually, similarly to the $\mathrm{Cd}$, were the eating habits of each sampled individual may influence the intake and, consequently, the accumulation of the metal (Salgado et al., 2015).

Thus, the intake of different food items may explain the variations in the concentrations of the metal among the animals from the same location, since it varies with the age and the sex of the individuals and the occupancy of different areas between the specimens, allowing the accumulation of the metal in different levels. Additionally, factors such as the effect of individual metabolism would influence $\mathrm{Pb}$ concentrations in dolphins, this being probably the most difficult factor to understand when working with wildlife fauna such as marine mammals.

In infants (as observed in the specimen $\mathrm{Sg} 01$ ), high concentrations of $\mathrm{Pb}$ can be explained by the mother to the infant transfers, which can occur by the capacity of the metal to penetrate the placenta and during the lactation. This transfer possible reflects the concentration of maternal skeleton and in humans this transfer may determine more than $50 \%$ of $\mathrm{Pb}$ level transferred to the fetus, causing the fetal blood to contain 
almost the same metal levels that the mother's blood (Chen et al., 2014). This deposit also contributes significantly as a source of lead to the fetus, in fetal skeleton training period (Chen et al., 2014).

Moreover, there is the possibility that these animals could be natural from others areas and that these concentrations may reflect the bioavailability of nearby areas. The studied region is located between two nominated impacted regions, the Paranaguá Estuary in the south and the Santos Estuary in the north, which houses two of the most important harbors of the Brazilian coast. However, there is no information about the concentrations of metals in Guianas dolphins from these areas.

Regarding the $\mathrm{Pb}$ toxicity and it possible adverse effects, in general, clinical signs of poisoning by $\mathrm{Pb}$ vary according to the degree and the duration of the exposure (Moreira \& Moreira, 2004). The case described by Shlosberg et al. (1997) shows the direct effects of lead poisoning resulting in death within a short period. The authors analyzed a bottlenose dolphin that died in an aquarium in Israel, few weeks after ingesting inadvertently 55 lead bullets $(25 \mathrm{~g})$ and verified a concentration of $3.6 \mu \mathrm{g} \mathrm{g} \mathrm{g}^{-1}$ in the liver. According to the authors, this concentration has been responsible for several dysfunctions in the animal's body with the observation of damages in the liver, kidneys, brain and the optic nerve.

However, chronic intoxication, which occurs through continuous ingestion of low concentrations as seen in wild animals, leads it to more subtle effects evident only on continuous observation, which may over time, induce sublethal effects and exceptionally lead it to death (Reijnders et al., 1999). In addition, the $\mathrm{Pb}$ stored in the skeleton can be remobilized into the circulation in situations that promote bone resorption as in physiological conditions (rapid growth of infants, pregnancy, lactation) and pathological conditions (infections, osteoporosis), thus providing a mechanism for delayed toxicity (Smith et al., 1996).

Metals can cause immunosuppression, secondary diseases and tumors (Reijnders et al., 1999; Das et al., 2000). They can influence the function of immunocompetent cells resulting in the humoral immunity suppression, as well as acute or chronic inflammatory processes leading to hypersensitivity and autoimmune diseases (Reijnders et al., 1999; Kakuschke \& Prange, 2007). Pellisso et al. (2008) demonstrated the adverse effects of $\mathrm{Pb}$ in the immune functions. The authors observed the suppression of lymphocyte proliferation in vitro in blood cells of captive dolphins (Tursiops truncatus) exposed to concentrations lower than $10 \mathrm{mg} \mathrm{L}^{-1}$, which may result in reduced resistance to infectious diseases (Pellisso et al., 2008).

Many researches have highlighted the possibility of a single kind of contaminant or the synergistic role of different substances in the increase of the susceptibility of affected animals to diseases (Das et al., 2000; Van Bressem et al., 2009a; Moura et al., 2011; Moura et al., 2014). Immunosuppressants contaminants seem to assist in the emergence of skins diseases (Van Bressem et al., 2009 a; Van Bressem et al., 2009b) and aggravate parasite infections in dolphins (Measures, 2001).

There are no studies regarding the incidence of skin diseases in the Guiana dolphins' population from the studied area. However, some cutaneous lesions observed in the animals by the Instituto de Pesquisas Cananéia (IPeC), including specimens used in this study (Figure $3 \mathrm{~A}$ ), suggests that these pathological conditions are already present among these dolphins. Others skin diseases, as lobomycosis-like disease and nodular skin disease were observed in Guiana dolphins from a very near coastal area, as a possible indicator of a compromised marine environment (Van Bressem et al., 2009 b).

The presence of the parasites, Braunina cordiformis in the stomach and Halocercus brasiliensis in the lungs, have been frequently observed in Sotalia guianensis (Marigo et al., 2010), and also seen in the population of the estuary (Figure 3 $\mathrm{B}$ and $\mathrm{C})$. When in large numbers, they can cause significant lesions that may affect the health and, subsequently, the animal's survival. Marigo et al. (2010), found the same two species of parasites in dolphins of the Cananéia region and in the coast of Paraná State and concluded that the presence of small dots of gastric lesions caused by B. cordiformis, it probably would not affect the health of the animals. However, the high amount of $H$. brasiliensis found in the lung and the evidence of parasitic pneumonias through histopathological analyzes in some animals indicated that this could be an important debilitating condition for the species.

It is still unclear how the level of these $\mathrm{Pb}$ concentrations may be affecting the health of this Guiana dolphin population. The effects of the chronic exposure are difficult to observe and may go unnoticed for years in natural populations and so far, cause-effects relations have not been established.

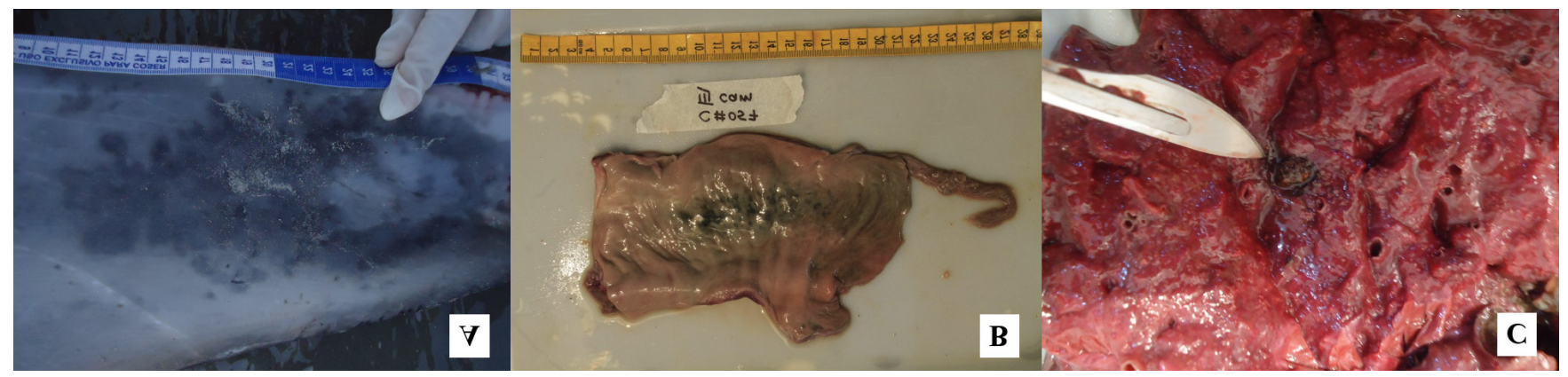

Figure 3. Pathological conditions observed in S. guianensis of the Estuarine-Lagoon Complex of Iguape-Cananéia. Images corresponds to Sg18 specimen. A) Dermal lesions on the caudal peduncle, indicating a cutaneous disease of unknown etiology. B) Necrosis in the third chamber of the stomach that may have been caused by the presence of a large number of $B$. cordiformis. C) H. brasiliensis cysts in lung bronchi. Source: IPeC File. 
In relation to the accumulation patters observed for the studies metals, marine mammals generally do not present significant differences between the sexes (O'shea, 1999; Caurant et al., 2006). This similarity in the accumulations of metals in liver between the genders was also observed for S. guianensis by Monteiro-Neto et al. (2003), Kunito et al. (2004) and Seixas et al. (2009). Moreover, the studies held by Carvalho et al. (2008), Seixas et al. (2009) and Lemos et al. (2013) found no correlation between the accumulation of the studied metals in the liver of the species and the body length, which is directly related to the age class (Rosas \& MonteiroFilho, 2002). However, high copper concentrations have been extensively observed in very young animals in marine mammals (Caurant et al., 1994; Kunito et al., 2004; MásRosa, 2009; Bilandžić et al., 2016).

\section{FINAL CONSIDERATIONS}

This study provides new data of concentrations of metals in liver of Guiana Dolphin, contributing to a better understanding of the accumulations in the specie and the impact of their habitat in the Brazilian coast.

We described the highest mean concentration of lead for the species, revealing the existence of an extensive environmental contamination by this element in the studied area. This direct measurement of the bioavailability of the metal in the dolphins may reflect their exposition through the lower trophic levels animals, highlighting the contamination of the food chain, which may be a matter of concern for the health of this small dolphin population. However, it is still necessary to evaluate how physiological parameters and the environmental conditions interfere in the process of bioaccumulation, since the total amount of these elements in the liver does not provide enough information about the origin of the contamination and the toxicity of the analyzed samples.

Thus, the author's incentives news research on the way to analyze the potential link between the level of these concentrations and depletory effects in these mammals health. For that, a long-term monitoring program is required, using detailed pathological studies combined with the consideration of the burden of chemical contaminants, in order to elucidate the forms of this metal in the environment, involving the evaluation of the food chain and establishing relationships between the availability and its toxicity. Moreover, we recommend the use of the species as a sentinel of environmental quality of their habitat due its biological and ecological peculiarities on the way to contribute to the conservation status of these animals in Brazil

\section{ACKNOWLEDGEMENTS}

We especially thank the Instituto de Pesquisas Cananéia and the Universidade Tecnológica Federal do Paraná for their logistic support in the field and laboratory analyses, respectively, and Dr. André Andrian Padial for the statistical analyses. We also thank the PETROBRAS sponsorship through their Programa PETROBRAS Ambiental (PETROBRAS Environmental Programme) (Contrato $n^{\circ} 6000.0063748 .10 .2$ ).

\section{REFERENCES}

ABESSA, D.M.S., MORAIS, L.G., PERINA, F.C., DAVANSO, M.B., RODRIGUES, V.G.S., MARTINS, L.M.P. \& SÍGOLO, J.B. 2014. Sediment geochemistry and climatic influences in a river influenced by former mining activities: The case of Ribeira de Iguape River, SP-PR, Brazil. O. J. Water Poll. Treat., 1(1): 43-53. http://dx.doi.org/10.15764/WPT.2014.01005

BILANDŽIĆ, N., ĐOKIC, M., SEDAK, M., ĐURAS, M., GOMERĈIĆ, T. \& BENIĆ, M. 2016. Copper levels in tissues of dolphins Tursiops truncatus, Stenella coeruleoalba and Grampus griseus from the Croatian Adriatic coast. Bull. Environ. Contam. Toxicol., 97(3): 367-373. http://dx.doi.org/10.1007/s00128-0161845-0

CARVAlHO, C.E.V., DI BENEDITTO, A.P., SOUZA, C.M.M., RAMOS, R.M.A. \& REZENDE, C.E. 2008. Heavy metal distribution in two cetacean species from Rio de Janeiro State, south-eastern Brazil. J. Mar. Biol. Assoc. UK, 88(6): 1117-1120. https://dx.doi.org/10.1017/S0025315408000325

CAURANT, F., AMIARD, J.C., AMIARD-TRIQUET, C. \& SAURIAU, P.G. 1994. Ecological and biological factors controlling the concentrations of trace elements $(\mathrm{As}, \mathrm{Cd}, \mathrm{Cu}$, $\mathrm{Hg}, \mathrm{Se}, \mathrm{Zn}$ ) in delphinids Globicephala melas from the North Atlantic Ocean. Mar. Ecol. Prog. Ser., 103: 207-219. http:// dx.doi.org/10.3354/meps103207

CAURANT, F., AUBAIL, A., LAHAYE, V., VAN CANNEYT, O., ROGAN, E., LÓPEZ, A., ADDINK, M., CHURLAUD, C., ROBERT, M. \& BUSTAMANTE, P. 2006. Lead contamination of small cetaceans in European waters - The use of stable isotopes for identifying the sources of lead exposure. Mar. Environ. Res., 62(2): 131-148. http://dx.doi.org/10.1016/j. marenvres.2006.03.007

CHEN, Z., MYERS, R., WEI, T., BIND, E., KASSIM, P., WANG, G., JI, Y., HONG, X., CARUSO, D., BARTELL, T., GONG, Y., STRICKLAND, P., NAVAS-ACIEN, A., GUALLAR, E. \& WANG, X. 2014. Placental transfer and concentrations of cadmium, mercury, lead, and selenium in mothers, newborns, and young children. J. Expo. Sci. Environ. Epidemiol., 24: 537544. https://dx.doi.org/10.1038/jes.2014.26

CHOUERI, P.K.G. 2015. Uso do bagre amarelo (Cathorops spixii) como modelo biológico de exposição e efeito de contaminantes no Complexo Estuarino-Lagunar Cananéia-Iguape-Peruíbe. PhD Thesis. Universidade Federal do Paraná, Curitiba, Brazil. 187p.

CREMER, M.J., PINHEIRO, P.C. \& SIMÕES-LOPES, P.C. 2012. Prey consumed by Guiana dolphin Sotalia guianensis (Cetacea, Delphinidae) and franciscana dolphin Pontoporia blainvillei (Cetacea, Pontoporiidae) in an estuarine environment in southern Brazil. Iheringia, 102(2): 131-137. http://dx.doi.org/10.1590/ S0073-47212012000200003

DAS, K., DEBACKER, V., PILLET, S. \& BOUQUEGNEAU, J.M. 2000. Heavy metals in marine mammals. In: Vos, J.V., Bossart, G.D., Fournier, M. \& O 'Shea, T. (eds), Toxicology of Marine Mammals. Washington D.C.: Taylor \& Francis, pp. 135-167.

FLORES, P.A.C. \& DA SILVA, V.M.F. 2009. Tucuxi and Guiana Dolphin (Sotalia fluvitilis and S. guianensis). In: Perrin, W.F., Wursig, B. \& Thewissen, J.G.M. (eds), Encyclopedia of Marine Mammals. 2nd edition. Amsterdam: Elsevier, pp. 1188-1192.

GERACI, J.R. \& LOUNSBURY, V. 1993. Marine Mammals Ashore: A Field Guide for Strandings. A\&M Sea Grant Publication, Texas. 305p. 
GUIMARÃES, V. \& SÍGOLO, J.B. 2008. Detecção de contaminantes em espécie bioindicadora (Corbicula fluminea) - Rio Ribeira de Iguape - SP. Quím. Nova, 31(7): 1696-1698. http://dx.doi. org/10.1590/S0100-40422008000700018

HAVUKAINEN, L., MONTEIRO-FILHO, E.L.A. \& FILLA, G.F. 2011. Population density of Sotalia guianensis (Cetacea: Delphinidae) in the Cananéia region, Southeastern Brazil. Ver. Biol. Trop., 59(3): 275-1284. http://dx.doi.org/10.15517/rbt. v0i0.3398

USEPA (Environmental Protection Agency). 1996. Ecological Effects Test Guidelines OPPTS 850.4200 Seed Germination/ Root Elongation Toxicity Test, Washington DC.

IBAMA (Instituto Brasileiro do Meio Ambiente e dos Recursos Naturais Renováveis). 2005. Protocolo de conduta para encalhes de mamíferos aquáticos. Rede de encalhe de mamíferos aquáticos do Nordeste, Recife, BR.

ICMBio (Instituto Chico Mendes de Conservação da Biodiversidade). 2011. Plano de ação nacional para a conservação dos mamíferos aquáticos: Pequenos cetáceos. Rocha-Campos, C.C., Câmara, I.G., Pretto, D.J. (org). ICMBio, Brasília, 132p.

IUCN (International Union for Conservation of Nature). 2017. Sotalia guianensis. Available in: <http://www.iucnredlist.org/ details/181359/0>. Accessed in: Feb. 1, 2018.

KAKUSCHKE, A. \& PRANGE, A. 2007. The influence of metal pollution on the immune system: A potential stressor for marine mammals in the North Sea. Int. J. Comp. Psychol., 20(2): 179193.

KEMPER, C., GIBBS, P., OBENDORF, D., STEVEN, M. \& LENGHAUS, C. 1994. A review of heavy metal and organochlorine levels in marine mammals in Australia. Sci. Total. Environ., 154(2-3): 129-139. http://dx.doi.org/10.1016/00489697(94)90083-3

KORN, M.G.A., OLIVEIRA, P.V., ROSA, S.M., SANTOS, G.L. \& TEIXEIRA, L.S.G. 2010. Determination of cadmium and lead in Cetacean Dolphinidae tissue from the coast of Bahia state in Brazil by GFAAS. Microchrm. J. 96(1): 12-16. https://dx.doi. org/10.1016/ j.microc.2010. 01.001

KUNITO, T., NAKAMURA, S., IKEMOTO, T., ANAN, Y., KUBOTA, R., TANABE, S., ROSAS, F.C., FILLMANN, G. \& READMAN, J.W. 2004. Concentration and subcellular distribution of trace elements in liver of small cetaceans incidentally caught along the Brazilian coast. Mar Pollut Bull., 49(7-8): 574-587. http://dx.doi.org/10.1016/j. marpolbul.2004.03.009

LAW, R.J., FILEMAN, C.F., HOPKINS, A.D., BAKER, J.R., HARWOOD, J., JACKSON, D.B., KENNEDY, S., MARTIN, A.R. \& MORRIS, R.J. 1991. Concentrations of trace metals in livers of marine mammals (seals, porpoises and dolphins) from waters around the British Isles. Mar. Pollut. Bull., 22: 183-191. https://dx.doi.org/10.1016/0025-326X(91)90468-8

LAW, R.J., JONES, B.R., BAKER, J.R., KENNEDY, S., MILNE, R. \& MORRIS, R.J. 1992. Trace metals in the livers of marine mammals from the Welsh coast and the Irish Sea. Mar. Pollut. Bull., 24(6): 296-304. https://dx.doi.org/10.1016/0025326X(92)90590-3

LEMOS, L.S., MOURA, J.F., HAUSER-DAVIS, R.A., CAMPOS, R.C. \& SICILIANO, S. 2013. Small cetaceans found stranded or accidentally captured in southeastern Brazil: Bioindicators of essential and non-essential trace elements in the environment. Ecotoxicol. Environ. Saf., 97:166-175. https://dx.doi. org/10.1016/j.ecoenv.2013.07.025

LOPES, X.M., SILVA, E., BASSOI, M., SANTOS, R.A. \& SANTOS, M.C.O. 2012. Feeding habits of Guiana dolphins, Sotalia guianensis, from south-eastern Brazil: New items and a knowledge review. J. Mar. Biol. Assoc. UK, 92(8): 1723-1733. http://dx.doi.org/10.1017/S0025315412000495

MAHIQUES, M.M., FIGUEIRA, R.C.L., SALAROLI, A.B., ALVES, D.P.V. \& ALVES, C.G. 2013. 150 years of anthropogenic metal input in a Biosphere Reserve: The case study of the CananéiaIguape coastal system, Southeastern Brazil. Environ. Earth Sci., 68(4): 1073-1087. http://dx.doi.org/10.1007/s12665-012-1809-6

MARIGO, J., RUOPPOLO, V., ROSAS, F.C.W., VALENTE, A.L.S., OLIVEIRA, M.C., DIAS, R.A. \& CATÃO-DIAS, J.L. 2010. Helminths of Sotalia guianensis (Cetacea: Delphinidae) from the South and Southeastern Coasts of Brazil. J. Wildl. Dis., 46(2): 599-602. https://dx.doi.org/10.7589/0090-3558-46.2.599

MASON, R., BAKKA, A., SAMARAWICKRAMA, G.P. \& WEBB, M. 1980. Metabolism of zinc and copper in the neonate: accumulation and function of $(\mathrm{Zn}, \mathrm{Cu})$ - Metallothionein in the liver of the newborn rat. Br. J. Nutr., 45(2): 375-389. https:// dx.doi.org/10.1079/BJN19810113

MÁS-ROSA, S. 2009. Estratégias para determinação de metais e selênio em tecidos de mamíferos aquáticos encalhados no litoral do estado da Bahia por Espectrometria Atômica. PhD Thesis. Universidade Federal da Bahia, Salvador, Brazil. 78p.

MONTEIRO-NETO, C., ITAVO, R.V. \& MORAES, L.E.S. 2003. Concentrations of heavy metals in Sotalia fluviatilis (Cetacea: Delphinidae) off the coast of Ceará, northeast Brazil. Environ. Pollut., 123(2): 319-324. http://dx.doi.org/10.1016/S02697491(02)00371-8

MOREIRA, F.R. \& MOREIRA, J.C. 2004. Lead kinetics in human body and its significance to health. Ciênc. Saúde Coletiva, 9(1): 167-181. http://dx.doi.org/10.1590/S1413-81232004000100017

MOURA, J.F., CARDOZO, M., BELO, M.S.S.P., HACON, S. \& SICILIANO, S. 2011. A interface da saúde pública com a saúde dos oceanos: produção de doenças, impactos socioeconômicos e relações benéficas. Ciênc. Saúde Coletiva, 16(8): 3469-3480. http://dx.doi.org/10.1590/S1413-81232011000900015

MOURA, J.F., HAUSER-DAVIS, R.A., LEMOS, L., EMINLIMA, R. \& SICILIANO, S. 2014. Guiana Dolphins (Sotalia guianensis) as marine ecosystem sentinels: Ecotoxicology and emerging diseases. Rev. Environ. Contam. Toxicol., 228: 1-29. http://dx.doi.org/10.1007/978-3-319-01619-1_1

O'HARA, T.M. \& O'SHEA, T.J. 2001. Toxicology. In: Direaulf, L.A \& Gulland, F.M.D., Handbook of marine mammal medicine. 2nd edition. Boca Raton: CRC Press, pp. 471-520.

O'SHEA, T.J. 1999. Environmental contaminants and marine mammals. In: Reynolds III, J.E. \& Rommel, A.S. (eds), Biology of Marine Mammals. Washington and London: Smithsonian Inst. Press, pp. 485-563.

OSHIMA, J.E.F., SANTOS, M.C.O., BAZZALO, M., FLORES, P.A.C. \& PUPIM, F.N. 2010. Home ranges of Guiana dolphins (Sotalia guianensis) (Cetacea: Delphinidae) in the Cananéia estuary, Brazil. J. Mar. Biol. Assoc. UK, 90(8): 1641-1647. http://dx.doi.org/10.1017/S0025315410001311

PELLISSO, S.C., MUNOZ, M.J., CARBALLO, M. \& SANCHEZVIZCAINO, J.M. 2008. Determination of the immunotoxic potential of heavy metals on the functional activity of bottlenose dolphin leukocytes in vitro. Vet. Immunol. Immunopathol., 121(34): 189-198. http://dx.doi.org/10.1016/j.vetimm.2007.09.009

REIJNDERS, P. J. H.; AGUILAR, A. \& DONOVAN, G. P. 1999. Report of the workshop on chemical pollution and cetaceans. J. Cetac. Res. Manag., 1: 1-42.

RODRIGUES, V.G.S., FUJIKAWA, A., ABESSA, D.M.S., HORTELLANI, M.A., SARKIS J.E.S. \& SÍGOLO, J.B. 2012. Uso do bivalve límnico Anodontites tenebricosus (Lea, 1834) no biomonitoramento de metais do Rio Ribeira de Iguape. Quím. Nova 35(3): 454-459. http://dx.doi.org/10.1590/S0100- 
40422012000300003

ROSAS, F.C.W., BARRETO, A.S. \& MONTEIRO-FILHO, E.L.A. 2003. Age and growth of Sotalia guianensis (Cetacea, Delphinidae) on the coast of Paraná State, Southern Brazil. Fish Bull.,101(2): 377-383.

ROSAS, F.C.W. \& MONTEIRO-FILHO, E.L.A. 2002. Reproduction of the Estuarine Dolphin (Sotalia guianensis) on the Coast of Paraná, Southern Brazil. J. Mammal., 83(2): 507-515. https://doi. org $/ 10.1644 / 1545-1542(2002) 083<0507$ :ROTEDS $>2.0 . C O ; 2$

SALGADO, L.D., CARVALHO-NETO, F.S. \& FILLA, G.F. 2015. Cadmium concentrations in Sotalia guianensis (Van Bénéden, 1864) in a tropical estuary, southeast of Brazil. Braz. J. Aquat. Sci. Technol., 19(1): 39-45. http://dx.doi.org/10.14210/bjast.v19n1.p39-45

SANTOS, M.C.O., ACUÑA, L. \& ROSSO, S. 2001. Insights on site fidelity and calving intervals of the marine tucuxi dolphin (Sotalia fluviatilis) in south-eastern Brazil. J. Mar. Biol. Assoc. UK, 81(6): 1049-1052. https://doi.org/10.1017/S0025315401005045

SEIXAS, T.G., KEHRIG, H.A., DI BENEDITTO, A.P.M., SOUZA, C.M.M., MALM, O. \& MOREIRA I. 2009. Trace Elements in Different Species of Cetacean from Rio de Janeiro Coast. J. Braz. Chem. Soc., 20(2): 243-251. http://dx.doi.org/10.1590/S010350532009000200008

SHLOSBERG, A., BELLAICHE, M., REGEV, S., GAL, R., BRIZZI, M., HANJ, V., ZAIDEL, L. \& NYSKA, A. 1997. Lead toxicosis in a captive Bottlenose Dolphin (Tursiops truncatus) consequent to ingestion of air gun pellets. J. Wildl. Dis. 33(1): 135-139. http://dx.doi.org/10.7589/0090-3558-33.1.135

SICILIANO, S., ALVES, V.C. \& HACON, S. 2005. Aves e mamíferos marinhos como sentinelas ecológicas da saúde ambiental: Uma revisão do conhecimento brasileiro. Cad. Saúde Colet., 13(1): 927-946.
SMITH, R.D., OSTERLOH, J.D. \& FLEGAL, A.R. 1996. Use of endogenous, stable lead isotopes to determine release of lead from skeleton. Environ. Health. Perspect., 104(1): 60-66.

TESSLER, M.G. \& SOUZA, L.A.P. 1998. Dinâmica sedimentar e feições sedimentares identificadas na superfície de fundo do Sistema Cananéia-Iguape, SP. Rev. Bras. Oceanogr., 46(1): 6983. http://dx.doi.org/10.1590/S1679-87591998000100006

VAN BRESSEM, M.F., RAGA, J.A., DI GUARDO, G., JEPSON, P.D., DUIGNAN, P.J., SIEBERT, U., BARRETT, T., SANTOS, M.C.O., MORENO, I. B., SICILIANO, S., AGUILAR, A. \& WAEREBEEK, K.V. 2009. Emerging infectious diseases in cetaceans worldwide and the possible role of environmental stressors. Dis. Aquat. Organ. 86(2): 143-157. http://dx.doi. org/10.3354/dao02101

VAN BRESSEM, M.F.; SANTOS, M.C.O. \& OSHIMA, J.E. 2009. Skin diseases in Guiana dolphins (Sotalia guianensis) from the Paranaguá estuary, Brazil: A possible indicator of a compromised marine environment. Mar. Environ. Res., 67(2): 63-68. http:// dx.doi.org/10.1016/j.marenvres.2008.11.002

YI, Y., YANG, Z. \& ZHANG, S. 2011. Ecological risk assessment of heavy metals in sediment and human health risk assessment of heavy metals in fishes in the middle and lower reaches of the Yangtze River basin. Environ. Poll., 159(10): 2572-2585. https://dx.doi.org/10.1016/j.envpol.2011.06.011

ZAPPES, C.A., ANDRIOLO, A., SILVA, F.O. \& MONTEIROFILHO, E.L.A. 2009. Potential conflicts between fishermen and Sotalia guianensis (Van Bénéden, 1864) (Cetacea, Delphinidae) in Brazil. Sitientibus 9(4): 208-214. 